* Materials

$\because$ Research

22333 Governors Highway

PIlgrim 8-8777
Richton Park Illinois 60471

$\downarrow$ Chicago telephone
- PUllman 5-4020

CFon ProreEs

$$
\text { COO- } 1477-6
$$

R. $3.00 ; \mathrm{mat}, 6 \mathrm{~s}$

\title{
DEVELOPMENT OF TEST PROCEDURES
}

Contract No. AT $(11-1)-1477$

FRACTURE TOUGHNESS OF REACTOR PRESSURE VESSEL STEELS

\section{Sponsor: DRD\&T Program Branch}

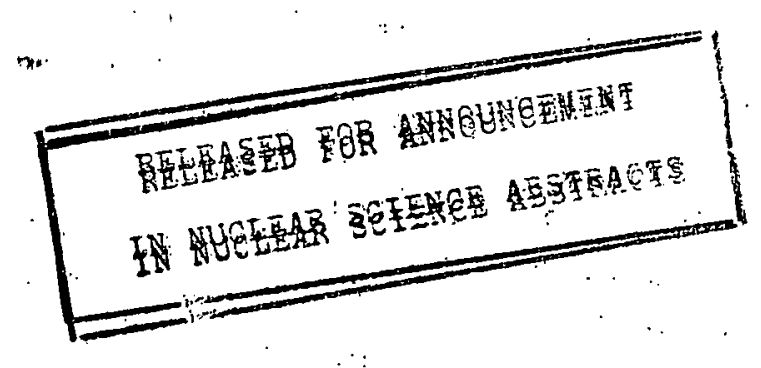

By

E. J. Ripling and P. B. Crosley

IN NUCTYAR SCIENEE AESTRACIS

RELEASED FOR ANNQUHCENENT

For the period August 1, 1966 to October 31, 1966

Is sued November 30,1966

\section{LEGAL NOTTCE}

States, nor the Commission an account of Government sponsored work. Neither the United A. Makes any warranty or representatlon acting on behalf of the Commission

racy. completeness, or usefulness of the informatlos or implied, with respect to the accu losed in this report may no B. Assumes ant or De any infor any liabillties with reapen to the use of or for damages reauling

As lnformation, apparatus, ployee or contrate above, "person acting on behalf of the commisla report.

employtractor of the Commisston or employ disseminates, or contractor of the Commisaton, or of such contractor, to the extent that with the Commisston, or access to, any information'pursuant to bich contractor prepares, 


\section{DISCLAIMER}

This report was prepared as an account of work sponsored by an agency of the United States Government. Neither the United States Government nor any agency Thereof, nor any of their employees, makes any warranty, express or implied, or assumes any legal liability or responsibility for the accuracy, completeness, or usefulness of any information, apparatus, product, or process disclosed, or represents that its use would not infringe privately owned rights. Reference herein to any specific commercial product, process, or service by trade name, trademark, manufacturer, or otherwise does not necessarily constitute or imply its endorsement, recommendation, or favoring by the United States Government or any agency thereof. The views and opinions of authors expressed herein do not necessarily state or reflect those of the United States Government or any agency thereof. 


\section{DISCLAIMER}

Portions of this document may be illegible in electronic image products. Images are produced from the best available original document. 
This report was prepared à an account of Government sponsored work. Neither the United Statés, nor the Commission, nor any person acting on behalf of the Commission:

A. Makes any warranty or representation, expressed or implied, with respect to the accuracy, completeness, or usefulness of the information contained in this report, or that the use of any information, apparatus, method, or process disclosed in this report may not infringe privately owned rights; or

B. Assumes any liabilities with respect to the use of, or for . damages resulting from the use of any information, apparatus, method, or process disclosed in this report.

As used in the above, "person acting on behalf of the Commission" includes any employee or contractor of the Commission, or employee of such contractior, to the extent that such employee or contractor of the Commission, or employee of such contractor prepares, disseminates, or provides access to, any information pursuant to his employment or contract with the Commission, or his employment with such contractor. 


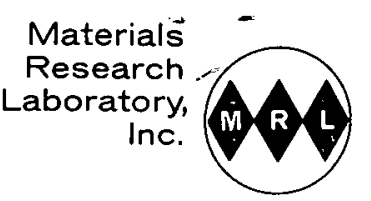

\section{A BST RACT}

Plane strain, room temperature, toughness values of $A 302-B$, which appear to be valid, have been measured on reasonable sized specimens. The toughness decreased, and approached the value for crack arrest toughness, as the loading rate was increased.

\section{INTRODUCTION}

Recent tests have concentrated on measurement of the plane strain fracture toughness, $K_{I f}$, of $A 302-B$ steel at room temperature: At this temperature the material has a higher ratio of toughness to yi eld strength than steels whose fracture toughness has been successfully measured to date. It is this high ratio, coupled with limitations on specimen size for the study of irradiation effects that have posed the major problem in the development of a satisfactory test procedure.

A further complication is introduced in evaluating the toughness of a mild steel like A302-B because of its high level of strain rate sensitivity. The latter is reflected not only in the significant elevations in yield strength with incruasing strain rate, but also in a substantially reduced critical stress intensity factor for the continued propagation of a running crack as compared with the value of $K_{\text {Ic }}$ for re-initiating a stationary crack, i. e., $K_{I C}$ for crack arrest is much less than $K_{I c}$ for crack initiation. Behavior. of the material in the process zone ahead of a fast running crack can be approximated by rapid loading of a specimen or structure containing a sta tionary crack. As the loading rate is increased, the fracture toughness, $\mathrm{K}_{\mathrm{If}}$, for crack initiation is lowered. Presumably, by increasing the strain rate, the value of $\mathrm{K}_{\mathrm{Ic}}$ for crack initiation can be made to approach the $\mathrm{K}_{\mathrm{Ic}}$ value for crack arrest. Hence, the fracture toughness of A302-B steel Ic at room temperature is not characterized by a single value of $\mathrm{K}_{\mathrm{IC}}$, but rather by $\mathrm{K}_{\mathrm{Ic}}$ as a function of strain rate. Fail-safe design requires an evaluation of the minimum $\mathrm{K}_{\mathrm{I}}$ for the operating temperature, and this presumably corresponds with the $\mathbb{K}_{\mathrm{Ic}}$ value for crack arrest:

To measure the room temperature fracture toughness of A302-B steel, a rapid loading technique has been developed. 'In addition to providing the most meaningful data for use in design, the use of high rate loading 
facilitates testing. The simultaneous increase in yield strength and decrease in toughness reduces specimen size requirements for obtaining plane strain fractures. Also, as the initiation toughness level approaches the arrest level, the possibility of measuring $K_{I C}$ for fracture arrest is enhanced.

Of particular concern in the tests described here was the verification that the measured values of toughness were valid $K_{I c}$ numbers. For this purpose specimens with different combinations of thickness and side groove depth were tested with the view of satisfying two criteria: that fracture surfaces be flat with little or no shear lip, and that the same value of fracture toughness be measured independent of thickness and side groove depth.

\section{SPECIMENS USED}

For all of the work DCB specimens contoured to $m=3$ in. $^{-1}$ were used (Fig. 1). With this shape the specimen compliance increases linearly with crack length, so that the conversion from applied load, $P$, to stress intensity factor, $\mathrm{K}$, is independent of the crack length. Three combinations of thickness and side groove depths were used, viz.: $\quad b=1.00 "$ with $\left(b_{n} / b\right)=$ $0.50 ; b=1.00^{\prime \prime}$ with $\left(b_{n} / b=0.75 ;\right.$ and $b=2.00^{\prime \prime}$ with $\left(b_{n} / b\right)=0.50$.

Compliance data for this specimen contour (Table I) were obtained from one-inch thick specimens of 5456-H321 aluminum alloy with $\left(b_{n} / b\right)=$ 0.50 . The measurements indicated $\mathrm{dC} / \mathrm{da}=3.30 \mu-\mathrm{in} / 1 \mathrm{~b}-\mathrm{in}$, corresponding to $\mathrm{m}^{\prime}=4.13 \mathrm{in}^{-1}$. This value of $\mathrm{m}^{\prime}$ was used to calculate a proportionality constant, A, relating the load and the stress intensity factor by the relation $P=A K$. The value of $A$ for each of the specimens used is given in Table $I$.

The location of the specimens in the A302-B steel plate, Fig. 2, was such that the crack plane was parallel to. the plate surface and located at the mid-thickness, and the crack propagation direction was parallel to the rolling direction. Although this orientation is of little practical importance for the evaluation of an actual structure, it has the advantage of reducing the machining time for specimen preparation and also of minimizing possible scatter caused by variation in material properties. 
The specimens were prepared for testing by extending a fatigue crack into the linear compliance region of the specimen. The length of the crack was ascertained from compliance measurements. That the crack front was, in fact, in the linear compliance region could be verified after testing by examination of the fracture surface.

Increasing load tests at high strain rates were conducted in a closed loop servo-hydraulic testing machine with crosshead displacement serving as the feedback signal. Load-time and deflection-time traces were recorded on an oscilloscope. Two different programmed signals were used. One procedure employed a triangular displacement pulse, with the maximum displacement corresponding to a load slightly above the anticipated crack initiation load. The loading rate was controlled by selecting the frequency of the triangular command signal. W! ith this technique it was possible to arrest the fast crack so that a second independent test then could be run on the same specimen by further extending the crack in fatigue, and then conducting another increasing load test. A second procedure was adopted to provide faster loading rates than could be obtained with a triangular command signal. In this procedure a "square wave" command signal was used so that the servo-valve was full open for the entire loading cycle. The loading rate, then, was limited only by the capacity of the hydraulic system and the compliance of the system.

\section{RESULTS}

All of the tests produced flat fracture surfaces. An example is shown in Fig. 3, for $a$ one inch thick specimen with $b / b=0.5$. The initial fatigue crack was extended to just beyond the saw-cut $\beta$-wing, and then the specimen was tested under pulse loading. This crack was arrested. The crack was extended again by fatigue, and retested as seen in Fig. 3, both the fatigue cracking and the rapid cracking produced flat fracture surfaces which are readily distinguishable.

Load-time and deflection-time traces for a specimen tested with the "square wave" command signal are shown in Fig. 4. The load trace was triggered at 15,000 pounds. Fracture initiation occurred seven msec later, 
Materials

Research

Laboratory,

inc.

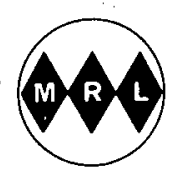

at a load of $19,900 \mathrm{lb}$, as evidenced by the abrupt discontinuity in the load and deflection traces. Accompanying crack propagation was a drop in load to $15,000 \mathrm{lbs}$. When the crack had arrested, the load again increased until fracture was initiated a second time, also at a load of 19,900 lbs. This single test, then, yielded three separate measurements of fracture toughness; fracture initiation from a fatigue crack required a load of 19,900 1bs. which gives $K_{I_{c}}=93 \mathrm{ksi} \sqrt{\mathrm{in}}$, this crack was arrested when the load had dropped to 15,000 ffs., which gives $K_{\text {Ic }}=70 \mathrm{ksi} \sqrt{\text { in }}$ for crack arrest, re-initiation re-

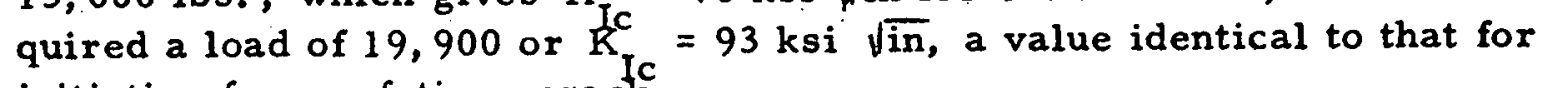
initiation from a fatigue crack.

Fracture toughness measurements from several tests are shown in Fig. 5. The values of $\mathrm{K}$ are plotted as a function of the time interval over which the load increased from zero to the fracture load. The data represent fracture initiation both.from fatigue cracks and from arrested fast cracks, and, just as in the particular test described above, the values of $\mathrm{K}_{\mathrm{Ic}}$ were not dependent on the type of starting crack.

The $\mathrm{K}$ Ic values are from specimens with the three different thickness and side groove combinations. There is no variation in the measured $K_{I c}$ values on these variables.

Although the data in Fig. 5 represent a relatively narrow range in strain rate (or loading time), a systematic decrease in $\mathrm{K}_{\mathrm{Ic}}$ with increasing strain rate is clearly indicated.

Cracks were not arrested in all of the specimens tested, and in many, vibration following rapid cracking contributed to the uncertainty in reading the load corresponding to the crack arrest. The $K_{I c}$ values for crack arrest which were obtained ranged from $65-80 \mathrm{ksi} \sqrt{\text { in. }}$

\section{DISCUSSION OF RESULTS}

The flat fracture surfaces and the fact that the measured $K_{\text {Ic }}$ values showed no dependence on thickness and side groove depth are evidence that the values are valid plane strain toughness measurements. For strain rates in the range used, $a$ one-inch thick specimen with $b_{n} / b=0.50$ provides valid $\mathrm{K}_{\mathrm{Ic}}$ measurements. If these thickness parameters placed the specimen in the plane strain to plane stress transition region, a decrease in measured toughness with increasing section thickness would be expected. The arbitrary 
criterion that the calculated plastic zone be small relative to the width across the crack plane cannot be applied until yield stress measurements at appropriately high strain rates have been made. It is to be expected that the yield stress at the high strain rates are much greater than the 65,000 psi measured at slow strain rates.

The scatter in measured values of $\mathrm{K}_{\mathrm{Ic}}$ per crack arrest is felt to be attributable to inadequate instrumentation and not to reflect the actual behavior of the material. Successive modifications in the testing procedure have reduced the objectionable vibration accompanying rapid fracture. In the curve shown in Fig. 4, which represents one of the more recent tests, the crack arrest load can be read with little difficulty. It is expected that subsequent tests will yield values in close agreement with the $70 \mathrm{ksi} \sqrt{\text { in }}$ for crack arrest obtained from this curve.

\section{CONCLUSIONS}

It appears possible to obtain valid measurements of plane strain toughness of $A 302-B$ steel in reasonable sized specimens by rapid loading techniques applied to side-grooved, contoured double cantilever beam specimens.

The crack initiation toughness of this strain rate sensitive material approaches its arrest toughness value as the loading rate is increased. Such a behavior has been previously postulated on the basis of indirect tests (i. e., strain haxdening exponent measurements) by J. Krafft and his associates. 
CONVERSION FROM LOAD (P) TO STRESS INTENSITY FACTOR (K) FOR SPECIMENS CONTOUREL TC $\mathrm{m}=3$

$$
\begin{aligned}
\not & =\frac{p^{2}}{2 b_{n}} \frac{d C}{d a} \\
\frac{d C}{d a} & =\frac{8}{E b} m^{\prime} \\
K & =\sqrt{2 E}=A P
\end{aligned}
$$

\begin{tabular}{|c|c|}
\hline & $\begin{array}{c}\text { b } \\
\text { inches }\end{array}$ \\
\hline
\end{tabular}

5456 Al

$$
1.00
$$

.50

3. 30

4. 13

5. 75

\section{A302-B Steel}

1.00

.50

(4. 13)

5.75

A302-B Steel

1.00

.75

(4.13)

4.69

A302-B Steel

2.00

1.00

(4.13)

2. 88 


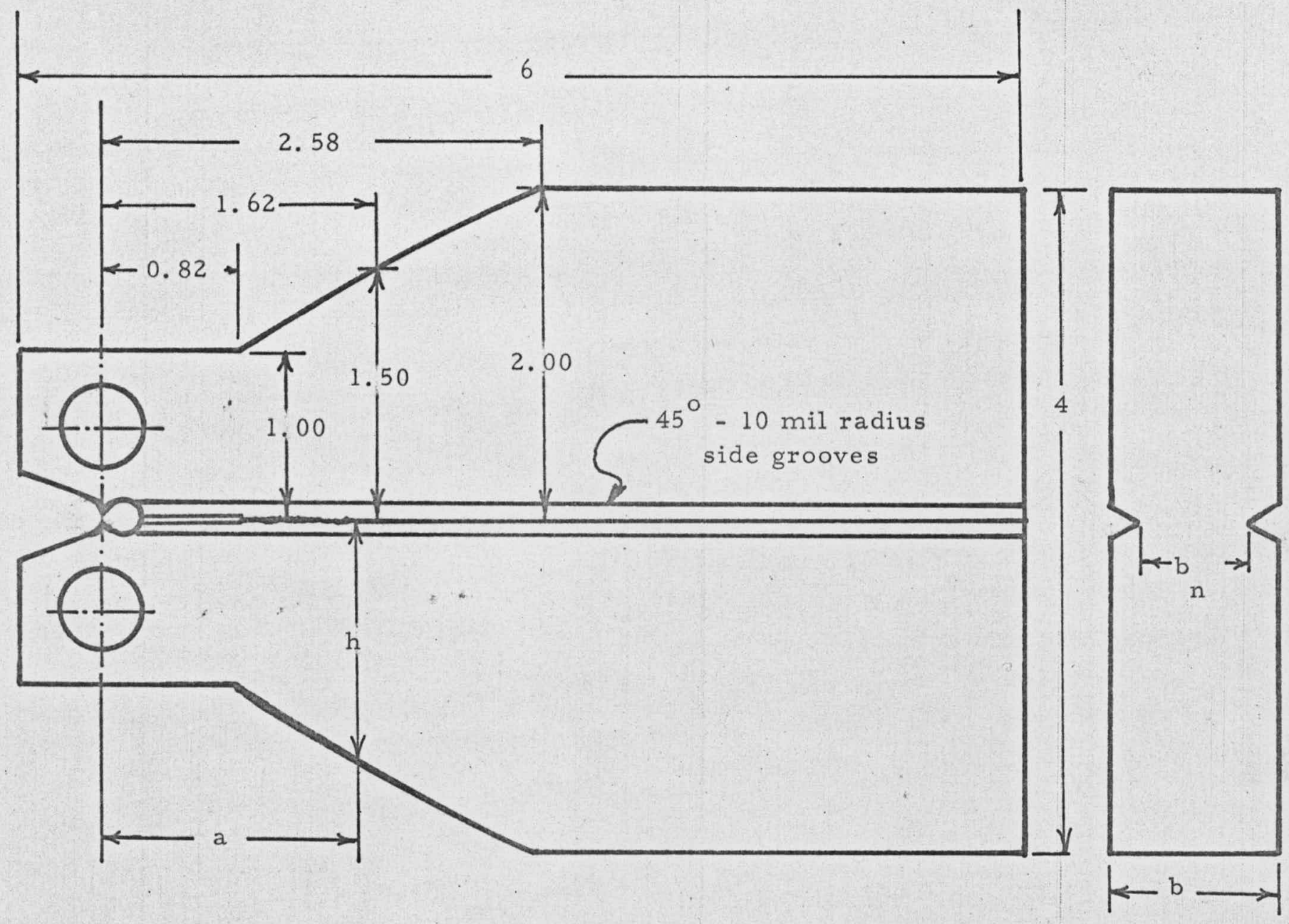

Fig. 1 CONTOURED DCB SPECIMEN USED FOR TESTING A302B STEEL. 


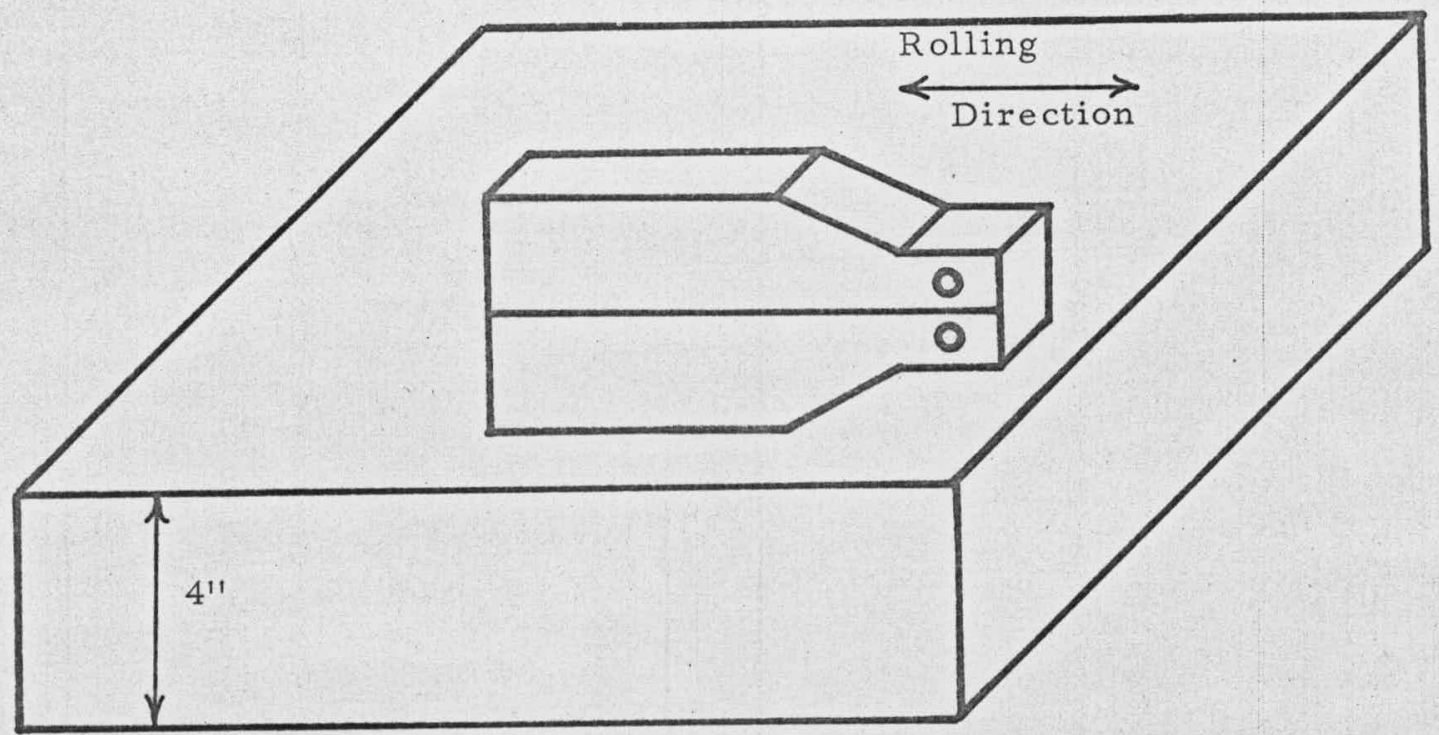

Tensile Data

UTS Y.S. Elong. R.A.

$\begin{array}{lllll}\text { Surface } & 98.5 & 82.0 & 26 & 70 \\ 1 / 4 \mathrm{~T} & 95.4 & 75.0 & 25 & 70 \\ 1 / 2 \mathrm{~T} & 86.0 & 65.7 & 26 & 70\end{array}$

Fig. 2 LOCATION OF SPECIMENS IN A302B STEEL PLATE. 


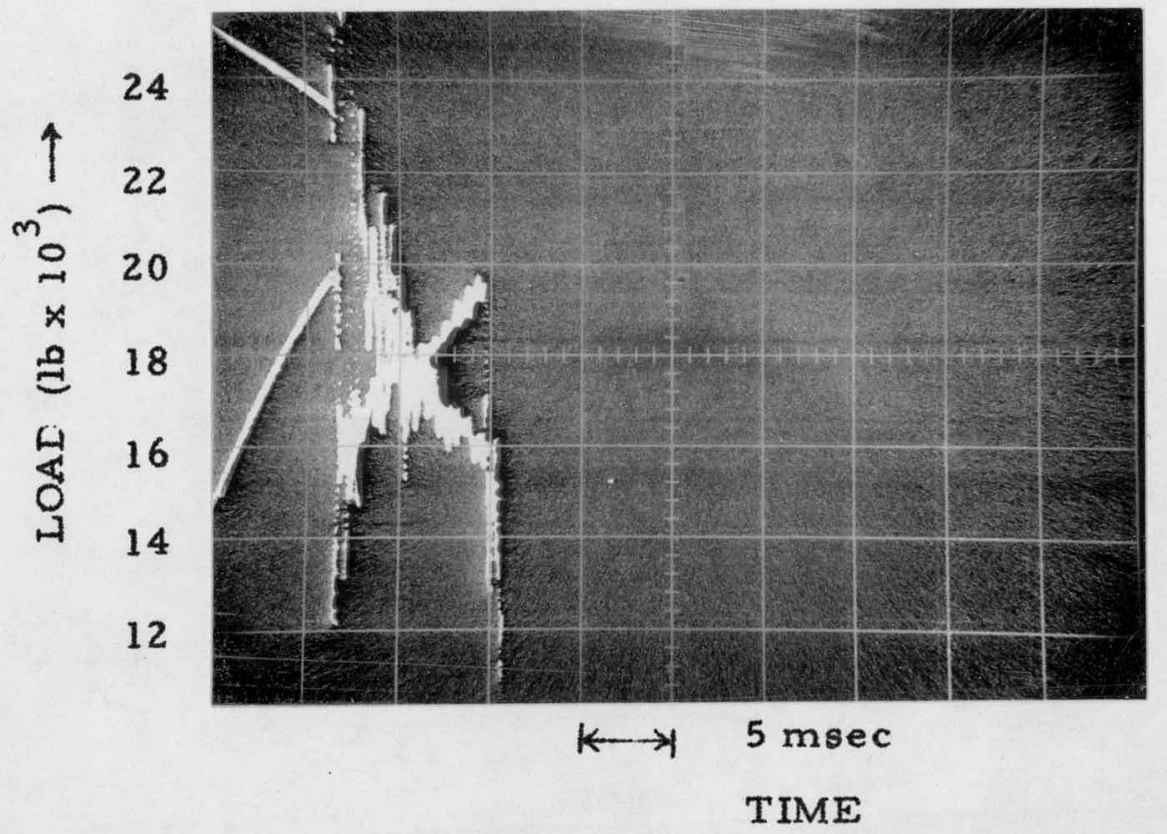

Fig. 3 LOAD-TIME AND DEFLECTION-TIME TRACES FOR PULSE-LOADED A302-B FRACTURE TOUGHNESS SPECIMEN. (Trace starting from upper Left is deflection, and from bottom Left is load.) 


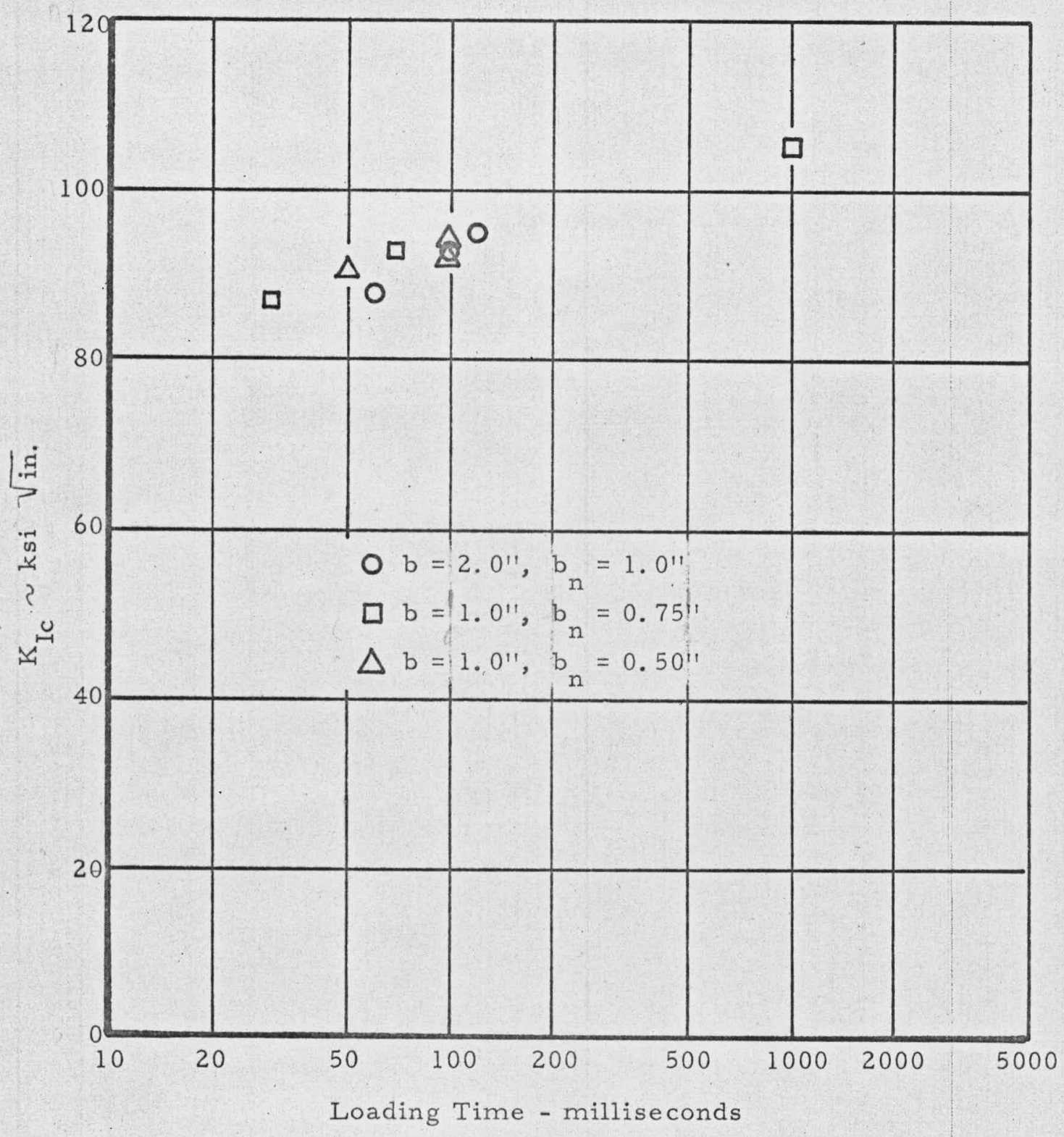

Fig. 5 DEPENDENCE OF ROOM TEMPERATURE $\mathrm{K}_{\text {IC }}$ ON LOADING TIME AND SPECIMEN DESIGN FOR A302B STEEL. 


\section{DISTRIBUTION LIST}

Dr. J. H. Kittel

Argonne National Laboratory

9700 South Cass Avenue

Argonne, Illinois 60440

Mr. F. R. Shober

Battelle Memorial Institute

Columbus Laboratory

$505 \mathrm{King}$ Avenue

Columbus, Ohio

Mr. J. C. Tobin (2 cys)

Dr. T. T. Claudson

Mir. A. L. Bement

Battelle Memorial Institute

Pacific Northwest Laboratory

P. O. Box 999

Richland, Washington 99352

Dr. D. H. Gurinsky

Brookhaven National Laboratory

Associated Universities, Inc.

Upton, L. I. , New York

Dr. T. A. Trozera

General Atomics Division

General Dynamics Corporation

P. O. Box 608

San Diego, California

Mr. L. E. Steele

Miss A. M. Sullivan

Mr. F. Loss

U. S. Naval Research Laboratory

Washington, D. C.

Mr. J. McGurty

Mr. John Moteff

General Electric Company

Nuclear Materials \& Propulsion Operation

P. O. Box 132

Cincinnati, Ohio
Mr. M. S. Wechsler

Mr. J. R. Weir

Oak Ridge National Laboratory

P. O. Box X

Oak Ridge, Tennessee 37831

Mr. Warren C. Francis

Atomic Energy Division

Phillips Petroleum Company

Idaho Falls, Idaho

U. S. Atomic Energy Commission

Washington, D. C. 20545

Division of Reactor Licensing

E. G. Case, Assistant Director

Division of Safety Standards

J. J. DiNunno, Assistant Director for Reactor Standards

A. B. Holt, Dhief, Technical Assistance Branch

Division of Reactor Devel. \& Technology

R. L. Cilimberg, Army Reactors Br.

J. L. Mershon, Analysis \& Eval. Br.

S. A. Szawlewicz, Research \& Devel. Branch

J. M. Simmons, Fuels \& Mat'ls.

Development Branch

W. L. R. Rice, Fuels \& Mat'ls.

Development Branch

Division of Naval Reactors

R. H. Steele

Division of Research

Dr. D. K. Stevens

Chicago Operations Office

F. C. Mattmueller (9 cys)

Cont. No. A $T(11-1)-1477$ 